UDC [616-057+613.6.06]:005

\title{
METHODOLOGICAL BASES \\ FOR DEFINITION OF ECONOMIC LOSSES \\ FROM OCCUPATIONAL DISEASES \\ IN THE POPULATION OF UIRRAINE
}

\author{
Kolodyazhna O. I.', Nahorna A. M.2
}

'National Academy of Statistics, Accounting and Audit, Kiev, Ukraine

2 SI «Institute for Occupational Health of NAMS of Ukraine», Kiev, Ukraine

The assessment of economic losses of the society due to occupational diseases recorded at enterprises, in the Fund of social insurance from accidents at work and occupational diseases, in the health system as well as because of premature mortality and low life quality is highlighted in the paper. The values of burden of diseases, recommended for use by experts of the World Bank, are presented. The years, lost due to untimely death of patients with occupational diseases, engaged in selected types of economic activity, have been defined.

The purpose of this study was to develop a method of defining one of the components of indirect losses of the society, i.e. lost years of healthy life due to occupational diseases. For this, the available methodical elaborations have been used, corrected and adapted to modern social and economic conditions.

Methods. The list of main items of losses from occupational diseases includes: 1) Expenses of enterprises (Ve ); 2) Expenses of the Fund for social insurance and the Pension Fund (Vf ); 3) Expenses of the budget in the public health system (Vh ).

The expenses of enterprises from occupational diseases include such components:1)Expenses on re-qualification of the suffered workers in the case of the lost of them general or professional work ability and expenses on education of new workers, accepted instead of the suffered (Ek);

2) Losses from the deficiency of products in the period of substitution of a patient by the worker of the similar level of qualification (Ez).

Results. The calculation made possible to conclude that losses from occupational diseases for enterprises, the Fund of social insurance, the Pension Fund and the budget of the health system in 2010 amounted to 4094,4 mln UAH or 0,37 \% GDP. According to the data of the Centre of Medical Statistics of the Ministry of Health of Ukraine the number of the dead in 2010, due to occupational diseases with the established cause-effect relation on their professional activity, made in Ukraine 313 individuals. The majority of dead were workers of the underground coal mining. In the anamnesis of the most of them there were recorded different chronic diseases of the respiratory system and pneumoconiosis, caused by chemical substances, gases, organic or nonorganic dusts. The age of the dead ranged from 38 in uranium and thorium ore mining to 84 years in coal mining. Among the dead only $15 \%$ survived up to the age of the life expectancy in Ukraine and only $2 \%$ - to the age, provided by the international standard.

Conclusion. 1. The calculation made it possible to conclude that losses from occupational diseases for enterprises, the Fund of social insurance, the Pension Fund and the budget of the health system amounted in 2010 to 4094,4 mln UAH or $0,37 \%$ GDP. 2. At present DALY is considered to be a unified index of the burden of diseases, making possible: a) to assess medicosocial losses of the society not only due to morbidity, disability or premature mortality, but, also, due to any combination of the above-mentioned causes; b) to assess direct and indirect economic losses from any causes or their combinations; c) to ground recommendations on the determination of strategic priorities in the national public health system.

By the present time DALY is used insufficiently in Ukraine, because of not adapted method for its assessment.

Key words: occupational morbidity, lost years of healthy life, DALY method

\section{Introduction}

Occupational health is a significant criterion of economic development of a country, a prerequisite of the social wellbeing of its population. The health status of workers is a direct reflection of the degree of health effects of unfavorable factors of endogenous and exogenous origin, heredity, excess and quality of medical care, in the first place.
An occupational disease means inability of the human body to adapt to constantly changing conditions of the work environment, occurring as a result of the professional human activity and specified by exceptional or primarily action of factors of the work environment, typical for a definite profession [1, 2 ]. By the data of the International Labor Organization near 160 million cases of occupational diseases are 
recorded in the world yearly and economic negative profit of the society, owing to this, makes $4-5 \%$ world GDP, i.e. more than $\$ 1251,3$ billions. [1, 3, 4].

The concept "economic losses" covers many aspects. It includes not only losses for treatment, rehabilitation, re-qualification for patients and care of disabled, but, also, worsening of the quality and shortening of the life span, decrease of health and work ability indices, decrease of the reproductive function in the population, increase of the load on the public health system, deficiency of GDP, directly or indirectly depending on the effect of the work environment.

As far back as in XVI century an English economist $V$. Petti made the first attempt to evaluate the human health as an element of the national rich, depending on the type of activity and ability to work. Later, A. Smith laid the basis for a comprehensive definition of the cost of the «human capital».

At the beginning of the XX century, in the period of rapid economic development of the society, there occurred a need for scientists to economically assess medico-demographic processes. The problem of defining losses attributable to premature mortality was studied by Y. Korchak-Chepurkovsky, L. Gersh, E. Filrose, D. Neiman, and others. Beginning from the second part of the XX century there were made attempts to estimate losses, due to worsening the population's health, engaged in economics of Ukraine. Among the scientists of the former Soviet Union, being involved in studying problems of economic assessment of medico-demographic processes, it is necessary to mention V. Korchagin, Y. Lisitsin, B. Prokhorov. Economic consequences of the effect of harmful work conditions on the human health were studied by G. Bushuyeva, V. Katsnelson, V. Tкасһоv [5].

However, irrespective of the great contribution of scientists, there are available only some methodical elaborations in the scientific literature and approximate estimations of losses from occupational diseases. Thus, the official statistics shows that the amount of economic losses from accidents at work and from occupational diseases in countries of the former Soviet Union do not exceed $2 \%$ GDP. However, according to the ILO estimations, the losses from diseases related to occupational activity in developing countries, can reach even 10 \% GDP. Such great difference, in our mind, is conditioned by difficulties of information-methodical character: imperfection of the method for estimation of economic losses and incomplete coverage of the data.
Economic losses cover not only expenses on treatment, rehabilitation, re-qualification of patients and support of the disabled, but, also, the losses, conditioned by direct or indirect effect of the work environment: decrease of the quality of life and shortening of the life span, decrease of health values and work efficiency, disorders of the reproductive function in the population, increase of the load on the public health system, failing to keep to the amount of GDP, i. e direct and indirect losses. The amount of direct economic losses, by the assessment of specialists, ranges from $10 \%$ to $30 \%$ of the general losses.

Expenses as a result of mortality due to an occupational disease include the sum of one help in the case of the death of the suffered person by a supporter and a family, funeral benefits and monthly insurance payments, who have a right in the case of the death of a suffered person. By the data of the Fund of social insurance the amount of expenses made 329, 1 mln UAH in 2010.

Expenses for compensation for damages for injured and members of their families is a support in the case of temporary disability up to rehabilitation or recognizing the disability, single help in the case of a long-term loss of professional work ability for an injured person, monthly insurance paying for the injured, sums of money for a moral damage, insurance paying to the injured for the period of his/her temporal transfer to more light work. In 2010 expenses for compensation for injured and members of their family made 3030,3 mln UAH.

Expenses by the budget of the health system include expenses on polyclinic service $\left(H_{p}\right)$ and in-patient treatment $\left(H_{S}\right)$ of patients with occupational diseases:

$$
V_{h}=H_{p}+H_{s} .
$$

Expenses from the budget of the health system on out-patient treatment depend on the number of visits to a polyclinic department within a period $\left(N_{p}\right)$ and the average cost of one visit $\left(\overline{Q_{p}}\right)$ :

$$
H_{p}=N_{p} \cdot \overline{Q_{p}} .
$$

Expenses from the budget of the health system for in-patient treatment make:

$$
H_{s}=N_{p} \cdot D_{s} \cdot \overline{Q_{s}},
$$

where $N_{s}$ - number of persons admitted to the hospital within a certain period with the diagnosis «occupational disease»; 
$D_{s}$ - average duration of a period for hospitalization for one patient;

$\overline{Q_{S}}-$ average cost of one day in the stationary.

Expenses from the budget of the health system can reached 251,2 mln UAH.

The calculations make possible to conclude, that losses from occupational diseases for enterprises, Fund for social insurance, Pension Fund and the budget of the health system made 4094,4 mln UAH or $0,37 \%$ of the GDP in 2010 .

The purpose of this study was to develop a method of defining one of the components of indirect losses of the society, i.e. lost years of healthy life due to occupational diseases. For this, the available methodical elaborations have been used, corrected and adapted to modern social and economic conditions.

\section{Methods}

The list of main items of losses from occupational diseases includes:

1) Expenses from enterprises $\left(V_{e}\right)$;

2) Expenses from the Fund for social insurance and the Pension Fund $\left(\mathrm{V}_{\mathrm{f}}\right)$;

3) Expenses from the budget in the public health system $\left(\mathrm{V}_{\mathrm{h}}\right)$.

The expenses from enterprises due to occupational diseases include such components:

1) Expenses on re-qualification of the suffered workers in the case of the lost of them general or professional work ability and expenses on education of new workers, accepted instead of the suffered $\left(\mathrm{E}_{\mathrm{k}}\right)$;

2) Losses from the deficiency of products in the period of substitution of a patient by the worker of the similar level of qualification $\left(\mathrm{E}_{\mathrm{z}}\right)$.

The total amount of expenses on education and re-qualification of workers can be expressed by the formulae;

$$
E_{k}=\overline{Q_{B}} \cdot N_{B} \cdot \overline{Q_{b}} \cdot N_{b} \cdot \overline{Q_{k}} \cdot N_{k},
$$

where $\overline{Q_{B}}, \overline{Q_{b}}$ - average amount of expenses of own money of an enterprise on education of one worker in production and in the educational institution, respectively;

$\overline{Q_{k}}-$ average amount of expenses for re-qualification of one worker;

$N_{B}, N_{b}$ - number of workers, who were trained in the production work and in the educational institution, respectively;
$N_{k}$ - number of workers, who were re-qualified.

The expenses from the Fund of social insurance and the Pension Fund made in 2010:

1) Expenses according to medical certificates $\left(F_{h}\right)$;

2 ) Expenses on sanatorium- and-spa treatment $\left(F_{l}\right)$;

3 ) Expenses on disability pensions according to a disease $\left(F_{j}\right)$;

4) Expenses as a result of death because of an occupational disease $\left(F_{c}\right)$;

$5)$ Expenses on reparation of damages to the suffered and to members of their families $\left(F_{g}\right)$.

Expenses according to medical certificates are defined as the value of the average-hourly salary for one full-time worker $\left(Z_{h}\right)$ per hours of absence of a worker at workplace because of the temporary disability $\left(T_{h}\right)$ and per number of full-time workers, who were not present at work because of a disease $\left(N_{h}\right)$ :

$$
F_{h}=Z_{h} \cdot T_{h} \cdot N_{h},
$$

Expenses on the sanatorium-and-spa treatment can be assessed according to the cost of route-sheets for treatment in sanatoria. They can be calculated according to the number of workers with $t$ type of pathology $\left(N_{t}\right)$ who need sanatorium treatment per the average cost of a route-sheet in the sanatorium of a specific type $\left(\bar{Q}_{t}\right)$ :

$$
F_{l}=\sum_{1}^{\mathrm{n}} N_{t} \cdot \bar{Q}_{t} .
$$

In Ukraine the cost of sanatorium-and-spa treatment in 2010 made 12,4 mln UAH.

Expenses for pensions on disability according to a disease are defined by the number of workers who received disability of $n$-group due to occupational disease per average amount of the pension of n-group per month:

$$
F_{l}=\sum_{1}^{\mathrm{n}} N_{n} \cdot \overline{Q_{n}} \cdot 12
$$

The calculated amount of expenses for disability pensions in 2010 made 387,9 $\mathrm{UAH}$.

Expenses as a result of mortality due to an occupational disease include the sum of one help in the case of the death of the suffered person by a supporter and a family, funeral benefits and monthly insurance payments, who have a right in the case of the death of a suffered person. By the data of the Fund of social insurance the amount of expenses made $329,1 \mathrm{mln} \mathrm{UAH}$. 
Expenses for compensation for damages for injured and members of their families is the support in the case of temporary disability up to rehabilitation or recognizing the disability, single help in the case of a long-term loss of professional work ability for the injured person, monthly insurance paying for the injured, sums of money for moral damage, insurance paying to the injured for the period of his/her temporal transfer to more light work. In 2010 expenses for compensation for injured and members of their family made 3030,3 mln UAH.

Expenses by the budget of the health system include expenses on polyclinic service $\left(H_{p}\right)$ and in-patient treatment $\left(H_{S}\right)$ of patients with occupational diseases:

$$
V_{h}=H_{p}+H_{s} .
$$

Expenses from the budget of the health system on out-patient treatment depend on the number of visits to a polyclinic department within a period $\left(N_{p}\right)$ and the average cost of one visit $\left(\overline{Q_{p}}\right)$ :

$$
H_{p}=N_{p} \cdot \overline{Q_{p}} .
$$

Expenses from the budget of the health system for in-patient treatment make:

$$
H_{s}=N_{p} \cdot D_{s} \cdot \overline{Q_{s}},
$$

where $N p$ - number of persons admitted to the hospital within a certain period with the diagnosis "occupational disease";

$D_{s}$ - average duration of hospitalization for one patient;

$\overline{Q_{S}}-$ average cost of one day in the stationary.

Expenses from the budget of the health system reached 251,2 mln UAH.

The most known integral indicator of the lost years of healthy life is DALY (disability adjusted life years), which shows the territorial and causal differentiation of medico-social losses of the society. It was proposed in 90 years by Murray and Lopez and was recommended for experts of the World Health Organization.

The concept of DALY is based on the postulate concerning diseases consequences, according to which any ailment can result not only in the loss of the quality of human life (limitations in communication, movements, ability to self-service, etc.), but in the untimely death as well. DALY is a linear sum of years of the potential life, lost because of the untimely death, and years, spent in a morbid (disabled) state.
Years, lost due to untimely death, are estimated by YLL index (years of life lost due to premature mortality), whereas years, lived with a disease or disability of various degree of burden - by YLD index (years lost due to disability). The main idea of DALY is in the calculation of the contribution of each of these components to the general number of the lost years of life $[8,9]$ :

- premature mortality

$$
Y L L=n \cdot L
$$

where $n$ - the number of dead in each age group, $L-$ standard duration of life in the year of death;

- morbid (disabled state)

$$
Y L D=I \cdot D W \cdot L
$$

where $I$ - the number of cases of a disease,

$L-$ mean duration of a disease up to remission or mortality (years);

$D W$ - burden of disability (weighted coefficient, showing the severity of a disease).

Below is the base mathematical model for defining the standard meaning of DALY [10]:

$\mathrm{DALY}=-\left[\frac{D \cdot C \cdot e^{-\beta a}}{(\beta+r)^{2}}\right]\left[e^{-(\beta+r) L}(1+(\beta+r)(L+a))-(1+(r+\beta))\right]$

where $D-$ a weighted coefficient of the burden of disease,

$a$ - meaning of the middle of the age interval, to which the recorded case was referred (or the age when the disease was set in),

$r$ - discount rate,

$L$ - duration of the state - such years of life, which, on the average, have been lost as a result of one case of disease or mortality. The value $L$ is calculated by the formulae of the arithmetic mean weighted from the lost years of life for a definite age period and the number of cases recorded in it, separately for each nosologic form,

$C$ and $\beta$ constants, showing the statistic weight of the age.

For calculation of DALY it is necessary to solve a number of questions in order:

- to define a potentially possible life span;

- to ground weighted coefficients of a disease burden and the "value" of healthy life for different age groups;

- to compare the value of the present healthy life with its value in future. 
The calculation of the lost years of life in the case of a disease or premature mortality provides for determination of a potential life span. The highest potential world rate of life span for women in Japan is used as the standard rate in the world practice, making 82 years (for men -80 years) [11]. However, for an ordinary Ukrainian citizen the probability to live less long life is very high. In addition, the period of life without health disorders, which cause disability and, with time, invalidity, is, also, very short. Taking into account very high gender differences in waiting for life span of our country-men, the definition of the lost years of healthy life should be made on the base of national tables of survival.

In order to provide the comparison of the lost years of healthy life due to different diseases, as well as due to impossibility of comparison of the time, lived with a disease or disability with the time, lost due to premature mortality, weighted average values for burden of disease (disability) are used. The weighted values range from " 0 " for the absolute health to " 1 " in the case of mortality, and are defined by the expertise, according to abilities of patients to be active in reproductive, educational, occupational spheres as well as in that concerning recreation. Table 1 shows the weighted values of burden of diseases, recommended for the use by experts of the World Bank [10, 13].

Thus, the weighted values defined by expertise, are: for tumor malignant $-0,9$; pneumoconiosis 0,4 ; psychic diseases $-0,5$; bone-muscular system

Table 1

Weighted values of burden of diseases

\begin{tabular}{|l|c|}
\hline \multicolumn{1}{|c|}{ Characteristics of the state of health } & Values \\
\hline $\begin{array}{l}\text { 1. Restricted ability to be active in at least one } \\
\text { sphere: reproductive, educational, occupational, } \\
\text { in recreation }\end{array}$ & 0,096 \\
\hline $\begin{array}{l}\text { 2. Restricted ability to be more active in any of } \\
\text { the following spheres: reproductive, educational, } \\
\text { occupational, in recreation }\end{array}$ & 0,220 \\
\hline $\begin{array}{l}\text { 3. Restricted ability to be active in two or more } \\
\text { of the following spheres: reproductive, educa- } \\
\text { tional, occupational, in recreation }\end{array}$ & 0,400 \\
\hline $\begin{array}{l}\text { 4. Restricted ability to be active in all below } \\
\text { mentioned spheres: reproductive, } \\
\text { educational,occupational, in the recreation sector }\end{array}$ & 0,600 \\
\hline $\begin{array}{l}\text { 5. The support is needed in every-day activity, } \\
\text { related to cooking, shopping, housekeeping, etc. }\end{array}$ & 0,810 \\
\hline $\begin{array}{l}\text { 6. The support is needed in every-day activity, } \\
\text { related to taking food, keeping to personal } \\
\text { hygiene, etc. }\end{array}$ & 0,920 \\
\hline
\end{tabular}

$-0,5$; hearing loss due to exposure to noise $-0,3$.

The problem of the value of healthy life for various age groups is one of the most discussed in DALY definition, because a year of life for any age is of equal worth. In the report of the World Bank it is mentioned that "the value" of healthy life, and so weighted values, respectively, increases in age from the birthday till 25 years old. Therefore, when defining DALY it is exactly a social value of different age periods of the human life is taken into account, where age dynamics of the level of personal social productivity is an indicator. In formulae 3, for definition of the indicator of the burden of diseases, age differences are taken into account, owing to the use of $C$ and $\beta$ constants.

Comparison of the value of the healthy life at present with its value in future is made by discounting. It is considered that the "value" of the healthy life at present is somewhat higher than its "value" in future. So, when defining DALY rates of discount are calculated at the level of $3 \%$.

Each health problem can probably result in:

1) mortality;

2) disability before mortality;

3) permanent disability;

4) full recovery.

As far as factors, determining the occupational health, are of the constant character and the information on the recovery of an occupational disease is not available, the calculation of DALY in this study is made by two possible scenario of the course of an occupational disease: disability before mortality and permanent disability. The procedure of determining the indicator of the burden of disease is considered by the data on the number of the dead from occupational diseases with the established cause-effect relation of the disease on their occupational activity by 01.01.2011.

According to the data of the Centre of Medical Statistics of the Ministry of Health of Ukraine the number of the dead in 2010, due to occupational diseases with the established cause-effect relation on their professional activity, made 313 individuals. The majority of the dead were workers of the underground coal mining. In the anamnesis of the most of them there were recorded different chronic diseases of the respiratory system and pneumoconiosis, caused by chemical substances, gases, organic or nonorganic dusts. The age of the dead ranged from 38 in uranium and thorium ore mining to 84 in coal mining. Among the dead only $15 \%$ survived up to the age of the life 
Table 2

Years, lost due to premature mortality

\begin{tabular}{|c|c|c|c|}
\hline \multirow{2}{*}{ Type of economic activity } & The number of the dead, & \multicolumn{2}{|c|}{ DALY, years } \\
\cline { 3 - 4 } & individuals & Premature mortality & Low life quality \\
\hline 05.10 Coal mining & 253 & 1654,7 & 1088,0 \\
\hline 07.10 Iron ore mining & 8 & 27,9 & 26,8 \\
\hline 07.21 Uranium and thorium ore mining & 9 & 63,7 & 41,9 \\
\hline Other types of economic activity & 43 & 196,0 & 118,1 \\
\hline
\end{tabular}

expectancy in Ukraine and only $2 \%$ - to the age, provided by the international standard.

Table 2 shows the assessed lost years of healthy life, calculated by the formulae (3), as a result of the premature mortality and low life quality of workers, on the assumption that each worker within 10 years, on the average, suffer from an occupational disease.

So, in 2010 the total number of the lost years of healthy life due to premature mortality from occupational diseases made 1942,3 DALY, and due to low life quality - 1274,8 DALY.

The amount of the deficient GDP is a cost parameter of economic losses of the society from occupational diseases. Regarding that by the data of the official statistics the GDP per capita in 2010 amounted to $23600 \mathrm{UAH}$, one can suppose that the rate of the deficient GDP, even without taking the inflation into consideration, reached 75,9 million UAH.

The previous calculations of direct economic losses show, that losses from occupational diseases in Ukraine, covering mainly losses of enterprises, Fund of social insurance, Pension Fund and the budget of the health system for 2010, reached 4094,4 mln UAH [6].

So, taking into account the deficient GDP, due to untimely death and low life quality, the amount of losses in the cost of GDP made 0,38 \%. Regarding that by estimation of the ILO specialists the level of losses from occupational diseases can range from $5 \%$ to $10 \%$, the problem of defining the cost of the deficient GDP requires further studies.

\section{References}

1. Kundiev, Y. I. Nahorna, A. M. 2007, Occupational health in Ukraine. An epidemiological analysis. Kiev: Avicenna (in Russian).

2. Bilyk, I. O. Disability. Available from: http://www. minjust.gov.ua/0/23359

3. Kundiev, Y. I., Nahorna, A. M. 2005, «Occupational morbidity in Ukraine within a long-term supervision", Ukrainian Journal of Occupational Health, no. 1, pp. 3-11. (in Ukrainian).

\section{Results}

The calculation made it possible to conclude that losses from occupational diseases for enterprises, the Fund of social insurance, the Pension Fund and the budget of the health system amounted to 4094,4 mln UAH or $0,37 \%$ GDP in 2010 .

\section{Conlusion}

1. The calculation made it possible to conclude that losses from occupational diseases for enterprises, the Fund of social insurance, the Pension Fund and the budget of the health system amounted to $4094,4 \mathrm{mln} \mathrm{UAH}$ or $0,37 \%$ GDP.

2. At present DALY is considered to be a unified index of the burden of diseases, making possible: a) to assess medico-social losses of the society not only due to morbidity, disability or premature mortality, but, also, due to any combination of the above-mentioned causes; b) to assess direct and indirect economic losses from any causes or their combinations; c) to ground recommendations on the determination of strategic priorities in the national public health system.

By the present time DALY is used insufficiently in Ukraine, because of unavailability of the adapted method for its assessment.

4. For the work safety. Available from: http://www.ilo. org/public/russian/region/eurpro/moscow/areas/ safety/docs/safework_fact_sheetrus1_1.pdf

5. Katsnelson, V. A., Bushuyeva, G. A., Tkachev, V. V., Polzik, E. V. 1988, Analysis of economic consequences of the effect of unfavorable work conditions and industrial pollution of the environment on the human health, and economic efficiency of preventive measures. Moscow, p. 43 (in Russian).

6. Kolodyazhna, O. I., Nahorna, A. M., Sokolova, M. P. 2012, «Main principles and methodological bases in the 
definition of economic losses due to occupational morbidity of the working population of Ukraine", Ukrainian Journal of Occupational Health, no. 29 (1), pp. 81-85 (in Ukrainian).

7. Fox-Rushby, J. A., Yanson, K. 2001, Calculating and presenting disability adjusted life years (DALYs) in costeffectiveness analysis. Health Policy Plan. WHO, Geneva.

8. Global health risks: mortality and burden of disease attributable to selected major risks. Geneva, WHO;2009.

9. Haagsma, J. A., Polinder, S., Lyons, R. A., Lund, J. Ditsuwan, V., Prinsloo, M., Veerman, J. L., van Beeck, E. F. 2012, Improved and standardized method for assessing years lived with disability after injury. Bulletin of the World Health Organization.

10. Murray, C. J. 1994, Quantifying the burden of disease; the technical basis for disability-adjusted life years. World Health Organization Bulletin OMS.
11. Nuria Homedes. 1995, The Disability Adjusted Life Year (DALY) Definition, Measurement And Potential Use, Available from: http://www.worldbank.org/html/ extdr/hnp/hddflash/workp/wp_00068.html.

12. Titarenko, L. V. Modern approaches to the procedure of integral assessment of health indices for railway transport tuberculosis workers. Available from: http: / /vestnik.mednet.ru/content/view/290/30/ lang,ru/.

13. Occupational risk. Theory and practice of assessment. 2011, Monograph /Eds. A. G. Hkrupachev, A. A. Khadartsev. Tula: Edition of Tula State University, 330 p. (in Russian)

14. Rostovtsev, V. N., Lomat, L. N., Ryabkov, O. I., Marchenkova, I. B., Kuzmenko, B. E. 2008, The procedure of the combined assessment of losses of health due to morbidity and mortality. Minsk, 28 p. (in Russian).

\title{
Колодя)жна О. І.', Нагорна А. М. ${ }^{2}$ \\ METОАОЛОГІЧНІ ЗАСААИ ВИВНАЧЕННЯ ЕКОНОМІЧНИХ ВТРАТ BIА ПРОФЕСІЙНОÏ ЗАХВОРЮВАНОСТI НАСЕАЕННЯ УКРАÏНИ
}

\author{
'Нашіональна академія статистики, обліку та аудиту, м. Київ \\ ${ }^{2} \Delta$ У «Інститут меАичини праші НАМН України», М. Київ
}

У статті наведено розрахунки економічних втрат суспільства від професійних захворювань підприємствами, Фонду соціального страхування від нещасних випадків на виробництві та профзахворювань, системи охоронии здоров’я, а також втрат за методом DALY - через передчасну смерть та неякісне життя. Наведено коефіцієнти тяжкості захворювань, рекомендовані до використання експертами Світового банку. Визначено роки, втрачені через передчасну смерть у хворих на професійне захворювання, працюючих в окремих видах економічної діяльності.

Мета дослідження. Розробити метод визначення одного з компонентів непрямих втрат суспільства, тобто втрачених років здорового життя, у результаті професійних захворювань. Використано методичні розробки, скореговані та адаптовані до сучасних соціальних та економічних умов.

Методи дослідження. Перелік основних статей втрат від професійної патології складається з:1) витрат підприємств $\left(\mathrm{V}_{\mathrm{e}}\right)$;2) витрат Фонду соціального страхування та Пенсійного фонду $\left(\mathrm{V}_{\mathrm{f}}\right)$; 3) витрат бюджету системи охорони здоров'я $\left(\mathrm{V}_{\mathrm{h}}\right)$. Витрати підприємств від професійних захворювань формуються з таких компонентів: 1) витрати на перекваліфікацію постраждалих працівників у випадку втрати ними загальної або професійної працездатності та витрати на навчання нових працівників, прийнятих на місце потерпілих $\left.\left(\mathrm{E}_{\mathrm{k}}\right) ; 2\right)$ збитки від недоотриманої продукції в період заміни хворого працівника працівником того самого рівня кваліфікації $\left(\mathrm{E}_{\mathrm{k}}\right)$.

Результати. Проведений розрахунок дозволяє зробити висновок, що втрати від професійної патології підприємств, Фонду соціального страхування, Пенсійного форду та бюджету системи охорони здоров'я становили 4094,4 млн грн, або 0,37 \% вартості ВВП у 2010 році. За даними Центру медичної статистики МОЗ України в 2010 році чисельність померлих від професійних захворювань зі встановленим причинно-наслідковим зв'язком хвороби з їх професійною діяльністю становила 313 осіб. Левова частка померлих - це працівники з підземного добування вугілля, у переважної більшості з яких в анамнезі є різноманітні хронічні хвороби органів дихання та пневмоконіози, викликані хімічними речовинами, газами, органічним та неорганічним пилом. Вік померлих коливався від 38 років у галузі добування уранових і торієвих руд до 84 років у галузі добування кам'яного вугілля. Серед померлих тільки 15 \% дожили до віку середньої очікуваної тривалості життя в Україні і лише 2 \% - до віку, визначеного міжнародним стандартом.

Висновки. 1. Проведений розрахунок дозволяє зробити висновок, що втрати від професійної патології підприємств, Фонду соціального страхування, Пенсійного форду та бюджету системи охорони здоров’я становили 4094,4 млн грн, або 0,37 \% вартості ВВП у 2010 році. 2. Нині DALY вважається єдиним універсальним вимірником тягаря хвороб, використання якого дозволяє: а) оцінити медико-соціальні втрати суспільства не лише в результаті захворюваності, інвалідності, або через передчасну смерть, а й у разі будь-якої комбінації цих причин; б) розрахувати прямі та непрямі економічні втрати від будь-якого типу причин та їхніх комбінацій; в) обгрунтувати рекомендації щодо визначення стратегічних пріоритетів національних систем охорони здоров’я.

На даний час в Україні DALY має обмежене використання через відсутність адаптованої методики його оцінювання.

Ключові слова: професійна захворюваність, втрачені роки здорового життя, метод DALY 


\title{
Колодяккная О. И.', Нагорная А. М.
}

\section{МЕТОАОЛОГИЧЕСКИЕ ОСНОВЫ ОПРЕАЕАЕНИЯ ЭКОНОМИЧЕСКИХ ЗАТРАТ ОТ ПРОФЕССИОНААЬНОЙ ЗАБОЛЕВАЕМОСТИ НАСЕАЕНИЯ УКРАИНЫ}

\author{
'Национальная акацемия статистики, учета и ауцита, г. Киев

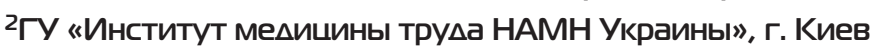

В статье дана оценка экономических потерь общества от профессиональных заболеваний, регистрируемых на предприятиях, в Фонде социального страхования от несчастных случаев на рабочем месте и от профессиональных заболеваний, а также в системе здравоохранения в результате преждевременной смерти и низкого уровня жизни. Представлены коэффициенты тяжести заболеваний, рекомендованные для использования экспертами Мирового банка. Определены годы, утраченные в результате преждевременной смерти, у больных с профессиональными заболеваниями, работающих в отдельных видах экономической деятельности.

Цель исследования. Разработать метод определения одного из компонентов непрямых потерь общества, то есть потерянных лет здоровой жизни в результате профессиональных заболеваний. Использованы имеющиеся методические разработки, скорректированные и адаптированные к современным социальным и экономическим условиям.

Методы исследования. Перечень основных статей потерь от профессиональных заболеваний включают: 1) расходы предприятий $\left(\mathrm{V}_{\mathrm{e}}\right)$; 2) расходы Фонда социального обеспечения и Пенсионного фонда $\left(\mathrm{V}_{\mathrm{f}}\right)$; 3) расходы бюджета системы здравоохранения $\left(\mathrm{V}_{\mathrm{h}}\right)$. Расходы предприятий от профессиональных заболеваний включают следующие компоненты: 1) расходы на переквалификацию пострадавших рабочих в случае утраты ими общей или профессиональной работоспособности и расходы на обучение новых рабочих, принятых вместо потерпевших $\left(\mathrm{E}_{\mathrm{k}}\right)$; 2) расходы от недополученной продукции в период замены заболевшего работника, такого же уровня квалификации $\left(\mathrm{E}_{\mathrm{k}}\right)$.

Результаты. Проведенный расчет позволяет сделать вывод, что расходы от профессиональных заболеваний предприятий, Фонда социального страхования, Пенсионного фонда и бюджета системы здравоохранения составили 4094,4 млн грн, или 0,37\% стоимости ВВП в 2010 году. Согласно данных Центра медицинской статистики М3 Украины в 2010 году число умерших от профессиональных заболеваний с установленными причинно-следственными связями заболевания с профессиональной деятельностью составило 313 человек. Большая часть умерших - работники подземной добычи угля, у большинства из которых в анамнезе были хронические заболевания органов дыхания и пневмокониозы, вызванные химическими веществами, газами, органической и неорганической пылью. Возраст потерпевших был от 38 лет в области добычи урановых и ториевых руд до 84 лет при добыче каменного угля. Среди умерших только 15 \% дожили до среднего года ожидания длительности жизни в Украине и только $2 \%$ - до года, установленного международным стандартом.

Заключение. Проведенный расчет позволяет сделать вывод, что потери от профессиональных заболеваний для предприятий, Фонда социального страхования, Пенсионного фонда и бюджета системы здравоохранения в Украине в 2010 году составили 4094,4 млн грн, или 0,37 \% стоимости ВВП в 2010 году. В настоящее время метод DALY считается единым универсальным методом для определения тяжести заболевания, использование которого позволяет: а) оценить медико-социальные потери общества не только в результате заболеваемости, инвалидности или преждевременной смерти, но и от любой комбинации таких причин; б) рассчитать прямые и непрямые экономические потери от причин любого типа или их комбинаций; в) обосновать рекомендации для определения стратегических приоритетов национальных систем здравоохранения.

На сегодняшний день в Украине метод DALY используется недостаточно, ввиду отсутствия адаптированной методики его оценки.

Ключевые слова: профессиональная заболеваемость, утраченные годы здоровой жизни, метод DALY

Надійшла: 11.07.2013 p.

Контактна особа: Нагорна Антоніна Максимівна, доктор медичних наук, професор, відділ епідеміологічних досліджень, ДУ «Інститут медицини праці НАМНУ», вул. Саксаганського, 75, м. Київ. Тел. +38 044 463-52-04. Елекронна пошта:yik@nanu.kiev.ua 